\title{
Does Ownership Structure of Emerging Market Firms Affect their Outward FDI? The Case of Indian Automotive and Pharmaceutical Sectors*
}

\author{
Sumon Kumar Bhaumik \\ Brunel University \\ Economics and Finance \\ School of Social Sciences \\ United Kingdom, UB8 3PH \\ Phone: +44 (0) 1895267247 \\ Fax: +44 (0) 1895269786 \\ Email: Sumon.Bhaumik@brunel.ac.uk \\ Nigel Driffield \\ Aston University \\ Economics and Strategy Group \\ Aston Business School \\ United Kingdom, B4 7ET \\ Phone: +44 (0) 1212043209 \\ Fax. +44 (0) 1212043306 \\ Email: n.l.driffield@aston.ac.uk \\ Sarmistha Pal \\ Brunel University \\ Economics and Finance \\ School of Social Sciences \\ United Kingdom, UB8 3PH \\ Phone: +44 (0) 1895266645 \\ Fax: +44 (0) 1895269786 \\ Email: Sarmistha.Pal@brunel.ac.uk
}

Running title: Ownership structure and outward FDI

Keywords: Institutions, Ownership structures, Family firms, Foreign investors, Outward FDI, Emerging market MNEs

April 2009

\footnotetext{
* The authors acknowledge support from the ESRC under award RES-062-23-0986. The authors would like to thank Stijn Classens and Jayesh Kumar for the use of the ownership data, Nina Blossinger and Yama Temouri for excellent research assistance, and session participants at the 2008 AIB (UK) conference, four anonymous referees, special issue editor Mike Peng and editorin-chief Lorraine Eden for helpful comments. They remain responsible for all remaining errors.
} 


\section{Author biographies:}

Sumon Kumar Bhaumik is a Senior Lecturer of Economics at Brunel University, and holds a Ph.D. from the University of Southern California. His main research interests lie in examining the impact of ownership structures and institutions on performance and behaviour of financial and non-financial companies, especially within the context of emerging market economies.

(Private information: Country of birth - India; Country of citizenship - United Kingdom)

Nigel Driffield is Professor of International Business at Aston Business School, and holds a Ph.D. from Reading University. His main research interests lie in modelling the cause and effect of FDI, the interactions between multinational firms and goods and factor markets, and the relationship between FDI and international technology flows.

(Private information: Country of birth - Kenya; Country of Citizenship - United Kingdom)

Sarmistha Pal is a Reader of Economics at Brunel University, and holds a Ph.D. from the London School of Economics. She is a development economist currently researching, among other things,on institutions and corporate governance in developing and transition economies. She is an expert on India and researched extensively on various aspects of Indian economic development. (Private information: Country of birth - India; Country of citizenship - India) 


\title{
Does Ownership Structure of Emerging Market Firms Affect their Outward FDI? The Case of Indian Automotive and Pharmaceutical Sectors
}

\begin{abstract}
This article examines the impact of ownership structures of emerging market firms, which are shaped by local institutions, on the decision of these firms to undertake outward FDI. Our results suggest that family firms and firms with concentrated ownerships, both ubiquitous in emerging markets, are less likely to invest overseas, and that strategic equity holding by foreign investors facilitates outward FDI. We conclude that organisational forms such as family firms, that are optimal outcomes of institutions prevailing in emerging markets, may be sub-optimal in a changing business environment in which outward FDI is necessary for access to resources and markets.
\end{abstract}

(100 words) 


\section{Introduction}

Looking beyond the OLI paradigm, more recent discussions of internationalization acknowledge the role of institutions in determining the extent and nature of internationalization (Peng, Wang, \& Jiang, 2008). Building on North (2005), Dunning and Lundan (2008) argue that institutional factors influence behaviour of firms, and we extend this to examining the extent and nature of internationalization of firms. Peng et al.(2008) suggest that a fundamental issue in IB is how firm characteristics that are shaped by local institutions influence strategic decisions in an ever-changing business environment. However, while the IB literature has examined the impact of local institutions on strategic choices like entry mode decisions of MNEs from developed countries (Meyer, Estrin, Bhaumik \& Peng, 2009), the impact of local institutions like business laws and regulations on the decision to internationalize (Yang, Jiang, Kang \& Ke, 2007), and internationalization strategies of emerging market firms (Athreye \& Kapur, 2009), the impact of institutionally determined firm characteristics on outward FDI from emerging markets remains relatively unexamined (Yamakawa, Peng, \& Deeds, 2008).

The firm characteristic in emerging markets that is most significantly affected by local institutions is ownership pattern (Yoshikawa \& McGuire, 2008). The institutions that shape ownership patterns include the role of trust and family ties in an environment of weak (legal) enforceability of contracts and social norms concerning altruism and bequest. Our paper represents a significant attempt to explore the relatively unexplored link between ownership patterns and outward FDI of emerging market firms. As pointed out by Lien, Piesse, Strange and Filatotchev (2005), neither of the two main strands of the IB literature, namely, the internationalisation theory (Buckley \& Casson, 1976; Rugman, 1981; Hennart, 1982) and the resource based theory (Lippman \& Rumelt, 1982; Barnay, 1986, 1991), discusses this link. While this was perhaps unimportant within traditional IB theory that has evolved specifically to analyse and explain FDI from the traditional set of source countries in the industrialized world, with the growing visibility of FDI from emerging economies, it is becoming imperative to extend the 
gamut of analysis to the emerging market MNEs (EMNEs). Yet, little is known about the motivation of emerging market firms to engage in outward FDI, and especially whether the ownership patterns that are an outcome of institutional contexts facilitate or hinder this avenue of their internationalization process. Therein lies the main contribution of this paper.

Using Indian firm level data, we examine the impact of two institutionally influenced aspects of firm ownership that are ubiquitous in emerging markets, namely, family control (which often coincides with business group affiliation) and concentrated ownership (Khanna \& Palepu, 1997), in explaining outward FDI. Our data are drawn from two industrial sectors, pharmaceuticals and automotives. During 2000-06, these two sectors accounted for nearly $30 \%$ of acquisitions of overseas assets by Indian firms, jointly tying for the first place with the much discussed ICT sector (Nayyar, 2008).

India accounts for over $20 \%$ of the global production of generic products within pharmaceuticals, and many of the firms are cash rich. However, indigenous R\&D is low, and acquisition of overseas firms with a pipeline of patents has been an integral part of the growth strategy (Athreye \& Godley, 2009). Indian pharmaceutical companies also view overseas acquisitions as the means to establish a market presence in the United States and the European Union (KPMG, 2006). Correspondingly, there has been a sharp increase in the value of such acquisitions. While an average overseas acquisition by an Indian pharmaceutical company stood at US\$116 million as late as 2004, by 2006 companies like Dr. Reddy’s were involved in acquisitions valued at over US\$500 million. The automotive sector, on the other hand, has long been a part of the global supply chain, largely by way of exports of auto components to the United States and Europe. Since 2000, led by companies like Tata Motors and Ashok Leyland, Indian automotive companies have rapidly expanded their activities overseas (Pradhan \& Singh, 2008). During 2000-07, these companies were involved in 22 Greenfield projects spread across 22 countries, with total investment of about US\$750 million. Their overseas acquisitions over roughly the same time period are valued at over US\$3,700 million. 
In an analysis of Indian multinationals' strategies, Ramamurti and Singh (2009) highlight the significant growth in Indian FDI. They point out that while many of the factors that encourage firms to remain family held as they grow, are most readily observed in India, India is by no means unique. Ramamurti and Singh (2009) point out that many of the phenomena that they highlight, and that are discussed here, such as the underdevelopment of both "hard" and "soft" institutions are evident in many emerging and developing countries. As such, rather than being a unique case, India offers a particular slant on a much wider phenomenon, that of firms from Emerging Economies investing in advanced countries.

In the absence of significant literature on the causal link between ownership patterns and outward FDI in the IB literature - Gallo and Sven (1991), Doukas and Lang (2003), and Lien et al. (2005) are important exceptions, we draw from relevant literature in related disciplines to develop plausible theories (or hypotheses) about this relationship. In particular, the behaviour of family controlled and group-affiliated firms have been extensively discussed in the management and corporate governance literature. Zahra (2003), for example, concludes that if family members actively participate in the management of companies, they be cautious about internationalization even when they attempt to maximize revenue from overseas markets. Zahra (2003) argues that this is in part due to the long gestation periods associated with overseas investment, and may therefore reduce the family's wealth in the short run, and, in part, because these family members are aware of the fact that managing business ventures overseas may require skills that they do not possess. Similarly, using case studies of (ethnic) Chinese family-owned MNEs from Singapore, Tsang (2001) has highlighted aspects of behaviour of family-owned EMNEs; for example, the effort put in by these EMNEs to transplant their family culture in their overseas operations. We discuss these and other related issues in more detail later in the paper.

In addition, we examine the impact of the stake taken by foreign investors in firms on their outward FDI, thereby linking our analysis to two important strands of the IB literature. Since a key contribution of foreign investors is to provide linkages with overseas markets, our analysis 
has implications for the linkage-leverage-learning (LLL) paradigm that has been proposed as an alternative to OLI in explaining outward investment from emerging markets (Mathews, 2006). ${ }^{1}$ Alternatively, if links with foreign investors generates information about overseas markets that are not publicly available, and if the cost of otherwise producing this information privately is high, then such links or associations can be viewed as resources for EMNEs, thereby linking our analysis to the resource based view of internationalization (see for example Barnay, Wright \& Ketchen. 2001), and the investment cycle hypothesis of Dunning (1986). The original investment cycle hypothesis of Dunning (1986) was concerned with explaining FDI flows at a macro level, though this has seldom been tested at the level of the firm. However, as Dunning (1992) shows, the analysis is akin to the subsequent resource based view of the (multinational) firm, in that some firms attracting foreign investors are a crucial resource to facilitate outward FDI.

\section{Ownership structure and overseas investment from emerging markets}

The literature on family businesses suggests that, for a variety of reasons, family control might have a positive impact on the competitiveness of firms. To begin with, these firms are more likely to undertake long-term investment, given that the interests of the strategic decision makers within such a firm are closely aligned with those of the firm itself (Dreux, 1990).Subsequently, that attachment to the family aligns the interests of different generations of managers. Further, while owners of non-family firms have to write and enforce detailed contracts to elicit the appropriate effort from the managers, in family-owned firms conflicts can be managed through informal mechanisms that could be less costly. The absence of the manager-owner agency problem in such firms therefore reduces monitoring costs, and makes the decision-making process flexible (Goffee \& Scasse, 1985; Daily \& Dollinger, 1992; Poza, Alfred \& Maheshwari, 1997). This, in turn, enables these firms to adjust better to changes in business environments,

\footnotetext{
${ }^{1}$ Recent evidence suggests that the internationalization strategies of EMNEs are consistent with the predictions of the LLL paradigm (Ge \& Ding, 2008).
} 
such that they are usually in a better position to withstand economic downturns (Dreux, 1990; Donckels \& Frohlich, 1991). A long-established family “name” might also signal quality and access to corridors of power. In sum, family-control is potentially a resource that a firm can leverage to enhance their competitiveness and achieve strategic objectives like entering new markets.

Habbershon and Williams (1999) have argued that this generic approach to strategic advantages of family-controlled firms is misleading. Drawing on research of Barnay (1991) and Grant (1991), among others, they highlight the fact that family-control can be a positive resource for a firm in the dynamic sense only if the non-family firms find it difficult or costly to devise mechanisms to replicate characteristics such lower transactions costs and flexible decisionmaking processes. Moreover, the advantages associated with family-control might not be transferrable across generations of the controlling family. There is a large literature that suggests that the performance of family-controlled firms is better than their non-family counterparts only if the founding family member is in control (Villalonga \& Amit, 2006; Andres, 2008).

Further, in contexts such as internationalization through outward FDI, some characteristics of family-controlled firms might prove to be a hindrance. Gallo and Sveen (1991) argue that family firms might be reluctant to internationalize through overseas FDI because it is difficult for them to transfer their business models that are rooted in local culture to a new context. Management of overseas operations typically requires skills that may not be available among family members, and hence outward FDI might require families to transfer considerable decision-making power to outside professionals, which families find disagreeable, especially in contexts where property rights are weak and informal contracts are part of the norm (Johanson \& Vahlne, 1977; Tsang, 2001; Zhang \& Ma, 2008). Rejection of meritocracy and dependence on family ties for choice of managers also ensure a state of "strategic simplicity" in family firms (Zahra, 2003), whereby these firms follow the same set of strategies over and over again, thereby passing up opportunities that are implicit in outward FDI. 
There is also significant evidence that families that have control over these firms expropriate returns that would otherwise accrue to minority shareholders in a variety of ways (Bertrand, Mehta \& Mullainathan, 2002; Baek, Kang \& Lee, 2006). Such expropriation typically goes unpunished, due to the dominant family position and the opacity of these firms.

Accordingly, family firms tend to be more reluctant to subject themselves to external scrutiny of regulators, investors, creditors and credit rating agencies. This aversion to scrutiny may deter them from undertaking outward FDI, a process that would require them to access capital markets and subject themselves to due diligence and regulatory scrutiny. On the other hand, however, outward FDI might actually be preferred because it can facilitate expropriation through mechanisms like transfer pricing. ${ }^{2}$

It is evident from the above discussion that while family-control may be a positive resource in many ways, it is by no means obvious that family-controlled firms would want to internationalize (or necessarily be capable of internationalization) through outward FDI. Clearly however, family firms are heterogeneous. Hence, even as family-controlled firms such as LG, Hyundai, Honda and Mitsubishi feature prominently in the global league tables on outward FDI, the above discussion suggests that these firms internationalize through outward FDI despite their family affiliation, because other characteristics of these firms (more than) offset the negative impact of factors like strategic simplicity, resulting in overseas investment. There is little evidence to suggest that the average family-controlled firm has significantly internationalized through outward $\mathrm{FDI}^{3}$. Indeed, it is perhaps reasonable to argue that if an average family firm with its strategic simplicity and attachment to its home business culture is not given an impetus to invest overseas by factors such as size of the domestic market and availability of resources in the

\footnotetext{
${ }^{2}$ We thank a referee for pointing this out to us.

${ }^{3}$ Note that in econometric terms this implies that the marginal impact of family ownership defined later in the paper - on outward FDI is negative. But this marginal impact can be offset by other firm characteristics such as profitability that constitute control variables in the regression model, such that our hypothesis is not inconsistent with the prominence of family-owned MNEs.
} 
home country, it would be reluctant to undertake outward FDI. We, therefore, hypothesize the following:

Hypothesis 1: Family-controlled emerging market firms will have a smaller proportion of their assets in overseas locations than non family firms.

As mentioned earlier, along with family control, concentrated ownership of shares is one other characteristic of emerging market firms. While ownership concentration is common among family-controlled firms, it is observed in other organisational forms as well, such that familycontrol and ownership concentration cannot be treated as being synonymous. Hence, we separately model its impact on a firm's decision to undertake outward FDI. While there is a significant literature on the impact of concentrated ownership on firm performance (see for example Bajaj, Chan \& Dasgupta. 1998 and Cho, 1998), there is virtually no coherent literature on the impact of ownership concentration on firm strategies, certainly not in the context of outward FDI. We, therefore, have to infer a plausible relationship between ownership concentration and outward FDI based on related literature.

There is a consensus that ownership concentration is an optimal response to weak corporate governance institutions, and that it has a positive impact on firm performance (Heugens, van Essen and van Oosterhout, 2009). To the extent that better corporate governance facilitates outward FDI, by removing inhibitions about scrutiny by creditors as well as external agencies like credit rating agencies and regulators, the natural corollary would be that firms with concentrated ownership are more likely to engage in outward FDI. It can similarly be argued that since ownership concentration, by definition, concentrates voting power in the hands of relatively few shareholders, it is easier to conjure majority support for initiatives such as outward FDI.

However, a number of factors offset this potentially positive relationship between ownership concentration and outward FDI. To begin with, firms with ownership concentration are 
likely to be reluctant to issue equity to finance outward FDI because such an action would dilute the control large shareholders have on the cash flow of these companies. Hence, such FDI is likely to be financed using debt or internal accruals. At the same time, outward FDI involves significant risk-taking, especially for emerging market firms that have relatively little experience in managing production units outside of their home countries. Ownership concentration implies that a company is less likely to use equity (which will dilute the ownership concentration of the chosen few) to fund risky projects. Debt financing of the project is then an option (see Driffield, Mahambere \& Pal, 2007), but it imposes a cost on managers who lose control over cash flow (Dewatripont \& Tirole, 1994). As with domestic investment therefore, the most attractive source of finance for overseas investment is the internal resources of the firm (Myers, 1984). Yet, if outward FDI is financed with internal resources then a decline in the firm's value on account of underperformance of any new operation significantly affects the wealth of large shareholders that are privy to the decision-making process, and this cost could be even greater in the event of financial distress. An important determinant of whether a firm with ownership concentration would invest overseas, therefore, is its degree of risk aversion.

The literature suggests that, on average, firms with concentrated ownership are risk averse. In a recent study, Garcio-Marco and Robles-Fernandez (2008) have found evidence of the negative impact of ownership concentration on risk taking. Their findings are consistent with evidence that suggests that an increase in the concentration of ownership of shares leads to a reduction in product diversification (Hill \& Snell, 1988) and that the likelihood of conglomerate merger is lower for firms with concentrated ownership (Amihud \& Lev, 1981). We, therefore, hypothesise the following:

Hypothesis 2: The proportion of an emerging market firm's assets held in the form of overseas investments will decline with the extent of concentration of ownership of its shares. 
The large IB literature on overseas market entry mode choice suggests that if markets for tangible and intangible resources are imperfect and/or if property rights and legal systems are imperfect, it is often efficient for a MNE to enter a new market by way of the joint venture (JV) with a local firm that has access to some or all of the relevant resources and informal relationships with firms, regulators and others that reduce the transactions cost of doing business (see Meyer et al., 2009, and the references therein). The rationale for a local firm to enter into an alliance with an MNE, often with the knowledge that the JV might be dissolved once the latter gains enough knowledge about the local business environment and develops its own network, is that the MNE has an innate capability, part of which might be passed on to the JV (and hence to the local firm) during the life of the partnership. As pointed out by Ramamurti (2009). unlike developed country MNEs, the capability of EMNEs lie in factors such as access to domestic resources (Russia, South Africa and Brazil), cheap domestic labour and/or large domestic markets (China, India and South East Asia), and large pool of high skilled labour (Israel). In other words, the innate capabilities of EMNEs are less transferable across international borders, thereby making these firms less attractive as JV partners for local firms in destination countries. EMNEs, therefore, have to use alternative ways of mitigating the problems associated with lack of knowledge and/or business experience of overseas destinations of outward FDI. They need another form of linkage that facilitates learning about the business environment in overseas business locations (Mathews, 2006). In a similar vein, Elango and Pattnaik (2007) illustrate how firms could draw on international experience of their network firms for internationalisation. Firms may build capabilities for internationalization through attracting foreign holdings. Further, this form of international exposure is particularly helpful for risk-averse family firms who lack the internal expertise to internationalise.

This line of argument is also embedded in Dunning’s (1986) investment cycle theory suggests that outward FDI may be facilitated by access to knowledge and expertise embedded in investors with international experience. Firms that have attracted foreign shareholders are more 
likely to be aware of investment opportunities abroad, either directly through inter-firm linkages or indirectly through managerial input from the foreign investors. ${ }^{4}$ In part, this access to information about overseas markets, business environments etc on the part of emerging market firms part of whose shares is owned by foreign investors may be endogenous, i.e., presence of foreign shareholders might be a manifestation of this knowledge rather than a causal effect of such shareholding pattern. In order to raise foreign capital, emerging market firms have to develop some knowledge about the preferences of overseas investors, undertake road shows in relevant countries, issue American (or Global) Depository Receipts and participate in related activities that adds to their knowledge of overseas business environments and regulatory practices. It might be argued that such knowledge, whether obtained in the process of attracting foreign investment or from foreign investors, would also make emerging market firms better aware of the risks associated with overseas investment. If anything, this line of argument reinforces the view that presence of foreign shareholders is likely to be positively associated with outward FDI. If sources of risks can be better identified and nature of risks better understood, there is a reduction in the uncertainty associated with overseas investment, thereby facilitating such investment (Dixit \& Pindyck, 1994).

Further, emerging market firms in which MNEs and other foreign investors have equity stake generally have better corporate governance quality, and hence are less likely to view engaging in FDI as an unreasonably risky strategy. The beneficial aspects of foreign equity holding in emerging market firms have been widely discussed in the literature. Ramaswamy, Li and Veliyath (2002), for example, argue that foreign investors exert greater control over Indian companies than other minority shareholders, with obvious implications for the quality of corporate governance. Similarly, Douma et al. (2006) show that foreign holdings in Indian companies are associated with positive performance, such that foreign ownership of equity can

${ }^{4}$ This view is consistent with the literature that suggests that MNE affiliation adds to export performance of developing country firms (Athukorala, Jayasuriya \& Oczkowski, 1995; Banga, 2007). 
act as a signal for better quality of management and corporate governance. The arguably better corporate governance practices adopted by firms that attract foreign investors are likely to make them less reluctant to be exposed to close scrutiny via outbound FDI. The presence of foreign investors might also help ease financing constraints by acting as a positive signal to investors, thereby facilitating loan syndication etc in the global capital market.

Thus, we hypothesize the following:

Hypothesis 3: Relative to firms without minority foreign holdings, both family-controlled and non-family emerging market firms with minority foreign holdings are associated with more outward FDI.

\section{Research Methodology}

\subsection{Sample and data}

As mentioned earlier in this paper, our analysis is based on firm-level data from the Indian pharmaceutical and automotive sectors. These represent large sectors of activity by well established firms (Government of India, 2006; Greene, 2007). Since the initiation of economic reforms in the early 1990s, turnover in both sectors has grown at over 20\% per annum. This growth has resulted in both scale economies and significant increase in cash flows, both of which facilitate overseas expansion. Not surprisingly, the pharmaceutical and automotive industries account for the second (20\%) and third (9\%) largest numbers of overseas acquisitions by Indian companies. While overseas expansion of the pharmaceutical companies is largely acquisitiondriven and United States and Europe centric, the automotive industry also accounts for a number of Greenfield projects, nearly two-thirds of which are in developing countries. As mentioned earlier, Indian pharmaceutical companies invest overseas to obtain a toehold in the large and growing generics markets in the United States and especially Europe, as also to gain access to patents and product lines of American and European companies that have historically been more 
R\&D-intensive than their Indian counterparts. Overseas investment of the Indian automotive companies is aimed at both market penetration - facilitated in part by acquisitions of distribution chains - and acquisition of brand capital (e.g., the acquisition of the Jaguar and the Land Rover brand by Tata Motors).

Our data are primarily taken from Orbis, a rich firm-level dataset that also provides information on overseas productive assets of the companies, thereby providing us with our measure for outward FDI. After accounting for missing data, we have information on 196 automotive firms and 581 pharmaceutical firms of Indian ownership. Of these, 80 automotive sector firms (41\%) and 44 pharmaceutical sector firms (7.5\%) report the ownership of assets outside India. The difference between the two sectors is in part attributable to the fact that the Indian automotive sector internationalised as early as the 1960s, much earlier than the Indian pharmaceutical sector, largely by way of joint ventures in other developing countries that were potential markets for the industry's products. The data coverage is from 2000 to 2006, resulting in 5410 firm-year observations.

We supplement the Orbis data with additional ownership information obtained from the Prowess data base that includes information on share-ownership of various categories of institutional and non-institutional owners, both domestic and foreign. Ownership data included in Prowess has been widely used in the relevant literature on Indian companies (e.g., Bertrand et al., 2002). We also have obtained information on the firm's affiliation to business groups, from the Capital Line data archive.

\subsection{Variables and specification}

Since our objective is to determine the impact of ownership on overseas investment of Indian firms, we use as the dependent variable in our analysis the proportion of a firm's assets that are held overseas (FDI). By expressing the overseas assets as a proportion of total assets, we 
automatically control for industry specific effects that might influence the dollar value of overseas investments.

Next, we describe our measures of the ownership variables. We employ two alternative measures of family control. The direct measure is taken from Prowess which allows us to identify whether a family is the single largest owner of shares a firm. Following Claessens et al. (2002), we construct a binary variable $F A M$ that takes the value unity if indeed a family is the single largest shareholder in a firm. However, it is likely that this measure will understate the influence that a family or closed network of owners would have on the firm's strategic decisions. It is now stylized that ownership structures involving crossholding, control pyramids etc result in larger degree of control and cash flow rights for the family than that reflected merely by their direct ownership of shares. We therefore employ the Capital Line data, which unambiguously identifies business group affiliations, usually a correlate of family control, and we construct second binary variable (BGR) that takes the value unity when a firm is affiliated to a business group. According to our data, the first measure suggests that only $18 \%$ of the firms in our sample are family-owned, an underestimate by most accounts, while the second measure gives us a more plausible figure of $40 \%$. We use these two indicators of family ownership separately in our regression models. The robustness of the estimates (qualitatively) should give us confidence about the ability of these binary indicators to capture the impact of family ownership on overseas investment.

We use the variable SHARECON, the Herfindahl index for all shareholdings, to capture the overall degree of ownership concentration. The average value of SHARECON is 0.088 , suggesting that in an average firm the ownership of shares is not as concentrated as one might have expected in a context where family businesses dominate.

Finally, we capture foreign investment in the firms with $F 10$ and F25, each a binary variable. These capture $10 \%$ and $25 \%$ ownership of shares by foreign investors, respectively. The former effectively distinguishes between portfolio investments which in these data are under 10\%. The latter signals a level of equity ownership at which foreign investors become more 
involved in the functioning of the firms. ${ }^{5}$ Since, foreign investors could influence the overseas investment decisions of family-controlled firms as well, we also include two interaction terms, namely, $I_{1}$ and $I_{2}$, between foreign ownership (F10, F25) and family ownership (FAM or BGR) ${ }^{6}$

We control for a number of firm-level characteristics. These are sales (SALES) and age (AGE) of a firm, the ratio of internal accrual of a firm to its total cash flow (CASH), number of Indian subsidiaries (INDSUB), the ratio of intangible assets to total assets (INTAN), debt-to-equity ratio (TDTA) and return on assets (PROFIT). In the interest of brevity, we do not discuss them in detail in this paper.

Our regression specification, therefore, is given by the following:

$$
\begin{aligned}
\text { FDI }_{i t}= & \beta_{0}+\beta_{1} \text { OWN }_{\mathrm{i}, \mathrm{t}-1}+\beta_{2} \text { SHARECON }_{\mathrm{i}, \mathrm{t}-1}+\beta_{3} \mathrm{~F}_{2} 5_{\mathrm{i}, \mathrm{t}-1}+\beta_{4} \mathrm{~F}_{10} 0_{\mathrm{i},-1}+\beta_{5} \mathrm{I}_{1}+\beta_{6} \mathrm{I}_{2} \\
& +\beta_{7} \text { SALES }_{\mathrm{i}, \mathrm{t}-1}+\beta_{8} \text { CASH }_{\mathrm{i}, \mathrm{t}-1}+\beta_{9} \text { AGE }_{\mathrm{i}, \mathrm{t}-1}+\beta_{10} \text { INDSUB }_{\mathrm{i}, \mathrm{t}-1}+\beta_{11} \text { INTAN }_{\mathrm{i}, \mathrm{t}-1} \\
& +\beta_{12} \text { TDTA }_{\mathrm{i}, \mathrm{t}-1}+\beta_{13} \text { PROFIT }_{\mathrm{i}, \mathrm{t}-1}+\mathrm{u}_{\mathrm{i}}+\varepsilon_{\mathrm{it}}
\end{aligned}
$$

when $i$ refers to the $i^{\text {th }}$ firms, $t$ and $t-1$ refer to time periods, $O W N$ is the indicator of family ownership which could be either FAM or BGR, $I_{1}$ is the interaction between $O W N$ and $F 10, I_{2}$ is the interaction between $O W N$ and $F 25, u_{i}$ is the firm-specific fixed effect and $\varepsilon_{i}$ is the iid error term. Our hypotheses have the following implications for the coefficient estimates:

$\begin{array}{lll}\text { Hypothesis 1 } & \text { implies } & \beta_{1}<0 \\ \text { Hypothesis 2 } & \text { implies } & \beta_{2}<0 \\ \text { Hypothesis 3 } & \text { implies } & \beta_{3}, \beta_{4}, \beta_{5}, \beta_{6}>0\end{array}$

To reiterate, as in any econometric analysis, each of our hypotheses capture the marginal impact of an ownership characteristic, i.e., the impact of the ownership characteristic after other firm characteristics have been controlled, on the outward FDI of the average firm in the sample.

\footnotetext{
${ }^{5}$ Sarkar and Sarkar (2000) demonstrated that foreign investors have an impact on performance of domestic India firms after they reach the threshold of about $25 \%$ equity ownership.

${ }^{6}$ There are no firms in the automotive sector that have $25 \%$ foreign holdings and are also family firms. There are however business group affiliated firms with this level of foreign held equity.
} 


\subsection{Modelling strategy}

Since the distribution of the dependent variable is left-censored at zero, the now stylized panel Tobit model is employed (Banga, 2007). The advantages of the panel nature of the data are twofold. First, it controls for firm-specific and time invariant unobserved factors that might influence the decision to invest overseas using firm-specific fixed effects. Second, in order to mitigate endogeneity problems of the explanatory variables, we lag them by one time period such that, for example, the sales in period $t-1$ affect the extent of overseas investment in period $t$.

The summary statistics and the correlation matrix for the dependent and explanatory variables are reported in Table 1. The correlation matrix indicates that with the sole exception of the correlation between PROFIT and CASH, there is no significant correlation among the dependent variables. ${ }^{7}$ However, estimates of models not reported in the paper suggest that dropping one or the other of these variables do not affect our results in any way. Further, in most of the regression models reported in later in this paper, coefficients of both these variables are significant, and this runs counter to the usual problem with multicollinearity, namely, high Rsquared values without any significant coefficients. Hence, we retain both variables in the regression specification.

\section{[Table 1 here]}

It is possible that that firms with better governance structures, or better protection of minority holdings, may be more likely to attract investment from abroad. If so, the foreign holdings variables may be endogenous in the outward FDI decision. While we are employing a panel structure with lags, we do test for endogeneity of the two indicators foreign ownership (F10 and F25) using the Tobit-specific methodology developed by Smith and Blundell (1986). For

\footnotetext{
${ }^{7}$ Standard VIF tests confirm that the multicollinearity is not a problem; the value of the test statistic is 3.4, well under the normal threshold of 5 .
} 
each of these variables, and each of the three samples (pooled, automotive sector, and pharmaceutical sector), the value of the test statistic, which follows a $t$ distribution, is less than one, and it is therefore appropriate to treat these variables as exogenous.

\section{Findings}

The panel data Tobit maximum likelihood estimates of equation (1) are summarised in tables 2-4. In each case, we not only estimate the model for the pooled data for the two industries including in the specification a sectoral control dummy for the automotive industry (CAR), but also estimate it separately for firms in automotive and pharmaceutical sectors.

We begin by estimating the baseline model, i.e., the model that includes in the specification the control variables mentioned above, but leaves out the ownership variables that are related to the hypotheses. The baseline specification is essentially one that is used in the literature to test the postulates of the OLI theory (see for example Driffield and Munday, 2000, and the references therein). The estimates of the baseline models for the automotive, pharmaceutical and pooled samples are reported in Table 2. The model performs well, with pseudo R-square values in the 0.32-0.38 range, and all of the coefficients have the expected sign, e.g., larger firms are more likely to engage in FDI, cash flow and profitability are positively associated with FDI, and the extent of outward FDI increases with the experience of the firms in managing Indian subsidiaries. There are also sectoral differences; expectedly, intangible assets influence outward FDI more in the pharmaceutical sector than in the automotive sector. Interestingly, outward FDI from a firm is negatively associated with its indebtedness.

Next, in Table 3, we report the estimation of our preferred specification, which includes the ownership variables. In Models 1, 3 and 5, we use the FAM variable as our proxy for family control, while in models 2, 4 and 6 we use BGR as our proxy for family control. We report both 
the pseudo $\mathrm{R}^{2}$ values and the correlation between the actual $(\mathrm{Y})$ and predicted $(\hat{\mathrm{Y}}$ ) values of the dependent variable; both suggest a reasonably good fit of our specification to the data.

[Table 2 here]

The implications of the estimates for our hypotheses are as follows:

Hypothesis 1: The indicator of direct family ownership FAM has a negative and significant effect (at $10 \%$ or lower level) on FDI in each sector as well as the pooled sample. However, while the business group affiliation variable $B G R$, a proxy for family control, has negative coefficients that are significant for the pooled sample and for the sample of firms in the automotive industry; the effect is negative but not statistically significant at $10 \%$ level for the pharmaceutical industry. We, therefore, find qualified support for our first hypothesis.

Hypothesis 2: The coefficient of the variable that measures concentration of ownership in the firms (SHARECON) is negative and significant at the $10 \%$ level in the pooled sample as well as in the separate samples of pharmaceutical and automotive firms. Hence, we have unqualified support for our second hypothesis.

Hypothesis 3: For both the pooled sample, and for the individual industries, our coefficient estimates suggest that significant shareholding by foreign investors facilitates overseas investment. Indeed, both F10 and F25 have positive and significant coefficients for the pooled sample as well as for each sector of our choice. Further, the coefficients of the interaction terms between the ownership variables and F10 and F25 (i.e., $I_{1}$ and $I_{2}$ ) have positive and significant coefficients for both the pooled sample and those for the individual industries, indicating that significant foreign ownership of equity can partially offset the unwillingness of family firms to invest overseas. In other words, we have unqualified support for our third hypothesis. 
The above discussion is predicated on the assumption that family or business group ownership is a discrete phenomenon, i.e., a firm is either a family owned (with business group affiliation) or it is not. While this assumption is in line with the literature on ownership types and firm performance, it may be instructive to test whether the scale of family or business group ownership is also important. We, therefore, re-estimate the model by replacing the dichotomous business ownership variables with continuous ones, namely, the share of the equity owned by the family (for FAM firms) or the business group (for BGR firms). The new estimates are reported in Table 4, and it is evident that the change in the measure of ownership does not change the results much relative to those reported in Table 3. Note, however, that while the inferences that can be drawn from them are similar, the continuous measures of family or business group holdings do not work quite as well as the discrete ones. This suggests that using a continuous measure of an ownership variable imposes a linearity in the relationship with outward FDI that is inappropriate. Indeed, given that all of the family firms have majority family holdings, it is likely that in absolute terms, family control is important, especially in the context of an emerging economy. However, it is perhaps less likely that if the family holding increases from say $51 \%$ to $55 \%$, or from $70 \%$ to $90 \%$ that this will have a significant difference of the willingness of that family firm to behave differently. ${ }^{8}$

\footnotetext{
${ }^{8}$ We also experimented with an alternative specification, one that includes both the continuous and discrete measures in the same regression, effectively testing whether an increased family holding has an additional effect over and above the fact that there is a majority holding. We do not report the results in this paper but they can be made available upon request. The baseline results of this specification are not sensitive to these changes. However the continuous variables become insignificant, with $t$ values less than one, such they add nothing to the explanatory power of the regression.
} 


\section{Conclusions}

Over the past decade, the world has witnessed what is arguably a new wave of globalisation, by way of outward FDI from emerging markets. Many emerging economies are characterised as having weak institutions. Two overlapping but distinct ownership characteristics, high degrees of family control and concentrated ownership, are seen as being optimal responses to the weak institutions of the home country, but nevertheless foster different strategic decision making processes from firms in the West (Young et al., 2008). In this paper, we analyse the impact of ownership on outward FDI from the Indian automotives and pharmaceutical sectors. In doing so, we address a key question in contemporary IB literature, namely, the impact of firm characteristics shaped by local institutions on strategic decisions regarding internationalization (Peng et al., 2008). We also examine the impact of foreign ownership on outward FDI of the Indian firms, thereby drawing implications for the LLL paradigm that emphasises the role of linkages in determining outward FDI (Mathews, 2006).

The single most important contribution of this paper is to demonstrate that organisational forms involving family control and concentrated ownership, while optimal within the home institutional environment, may actually have a detrimental impact on outward expansion. We also find that outward FDI is facilitated when emerging market firms develop strategic relationships with foreign investors. In this respect India offers a unique lens on a widely acknowledged but under researched area, the drivers and limitations to internationalisation of emerging market firms. The practical implication of this result is that in the foreseeable future outward FDI from emerging markets might be limited to a relatively small number of entities like the Tata Group that have significant strategic relationships with foreign investors. Aside for the implications for IB scholars, this result also has implications for policymaking in the current economic environment in which the emerging market companies are expected to lead the climb out of the recession through their investment in both domestic and overseas economies. 


\section{References:}

Amihud, Y. \& Lev, B. 1981. Risk reduction as a managerial motive for conglomerate mergers, Bell Journal of Economics, 12: 605-617.

Andes, C. 2008. Large shareholders and firm performance: An empirical examination of founding family ownership, Journal of Corporate Finance, In press.

Athreye, S. \& Godley, A. 2009. Internationalization and technological leapfrogging in the pharmaceutical industry. Industrial and Corporate Change, 18(2): 295-323.

Athreye, S. \& Kapur, S. 2009. Introduction: The internationalization of Indian and Chinese firms - trends, motivation and strategy. Industrial and Corporate Change, 18(2): 209-221.

Athukorala, P., Jayasuriya, S., \& Oczkowski, E. 1995. Multinational firms and export performance in developing countries: Some analytical issues and new empirical evidence. Journal of Development Economics, 46: 109-122.

Baek, J-S., Kang, J.K., \& Lee, I. 2006. Business groups and tunnelling: Evidence from private securities offerings by Korean chaebols. Journal of Finance, 61: 2415-2449.

Bajaj, M, Y-S. Chan and S. Dasgupta. (1998). The relationship between ownership, financing decisions and firm performance: A signalling model, International Economic Review, 39(3), 72344.

Banga, R. 2007. The export-diversifying impact of Japanese and US foreign direct investments in the Indian manufacturing sector. Journal of International Business Studies, 37: 558-568.

Barney, J.B. 1986. Organizational culture: Can it be a source of sustained competitive advantage? Academy of Management Review, 11(3): 656-665.

Barney, J.B. 1991. Firm resources and sustained competitive advantage, Journal of Management, 17(1): 99-120.

Barnay, J., Wright, M. \& Ketchen, D.J. (2001) The resource-based view of the firm: ten years after 1991. Journal of management, 27, 625-641.

Bertrand, M., Mehta, P., \& Mullainathan, S. 2002. Ferreting out tunnelling: An application to Indian business groups. Quarterly Journal of Economics, 117: 121-148.

Bertrand, M., Johnson, S., Samphantharak, K., \& Schoar, A. 2008. Mixing family with business: A study of Thai business groups and the families behind them. Journal of Financial Economics, 88: 466-498.

Buckley, P.J. \& Casson, M.C. 1976. The Future of the Multinational Enterprise, Homes \& Meier: London.

Cho, M. H. (1998). Ownership Structure, Investment, and the Corporate Value: An Empirical Analysis, Journal of Financial Economics, 47, 103-121. 
Claessens, S, Djankov, S., Fan, J.P.H., \& Lang, L.H.P. 2002. Disentangling the incentive and entrenchment effects of large shareholdings. Journal of Finance, 57, 2741-2471.

Daily, C.M. \& Dollinger, M.J. 1992. An empirical examination of ownership structure in family and professionally managed firms, Family Business Review, 5(2): 117-136.

Dewatripont, M. \& Tirole, J. 1994. A theory of debt and equity: Diversity of securities and manager-shareholder congruence, Quarterly Journal of Economics, 109(4): 1027-1054.

Dixit, A.K. \& Pindyck, R.S. 1994. Investment Under Uncertainty, Princeton, NJ: Princeton University Press.

Doukas, J.A., \& Lang, L.H.P. 2003. Foreign direct investment, diversification and firm performance. Journal of International Business Studies, 34(2), 153-172.

Douma, S., George, R., \& Kabir, R. 2006. Foreign and domestic ownership, business groups, and firm performance: Evidence from a large emerging market. Strategic Management Journal, 27: 637-657.

Dreux, D. R. (1990) Financing family business: Alternatives to selling out or going public, Family BusinessReview, 3(3): 225-243.

Driffield, N., Mahambare, V. \& Pal, S. 2007. How ownership structure affects capital structure and firm performance? Recent evidence from East Asia, Economics of Transition, 15: 535-573

Driffield, N. \& Munday, M. 2000. Industrial performance, agglomeration, and foreign manufacturing investment in the UK, Journal of International Business Studies, 31: 21-37.

Donckels, R. \& Fröhlich, E. 1991. Are family businesses really different? European experiences from STRATOS, Family Business Review, 4(2): 149-160.

Dunning, J.H. 1986. The investment cycle revisited. Weltwirtschaftliches Archiv, 122: 667-677.

Dunning, J.H. 1992. Multinational enterprises and the global economy. London: Prentice Hall.

Dunning, J.H., \& Lundan, S.M. 2008. Institutions and the OLI paradigm of the multinational enterprise. Asia Pacific Journal of Management, 25: 373-393

Elango, B \& Pattnaik, P. (2007) Building capabilities for international operations through networks: a study of Indian firms Journal of International Business Studies 38: 541-555

Gallo, M.A., \& Sveen, J. 1991. Internationalizing the family business: Facilitating and restraining factors. Family Business Review, 4: 181-190.

Garcia-Marco, T., \& Robles-Fernandez, M.D. 2008. Risk taking behavior and ownership in the banking industry: The Spanish evidence. Journal of Economics and Business, 60: 332-354.

Ge, G.L. \& Ding, D.Z. 2008. A strategic analysis of surging Chinese manufacturers. Asia Pacific Journal of Management, 25: 667-683. 
Goffee, R., \& Scase, R. 1985. Proprietorial control in family firms: Some functions of 'quasiorganic’ management systems. Journal of Management Studies, 22(1): 53-68.

Government of India 2006. Draft automotive mission plan, Ministry of Heavy Industries and Public Enterprises, Government of India, New Delhi.

Grant, R.M. 1991. The resource-based theory of competitive advantage: Implications for strategy formulation. California Management Review. 33(3): 114-135.

Greene, W. 2007. The emergence of India's pharmaceutical industry and implications for the US generic drugs market, Working paper no. 2007-05-A, Office of Economics, US International Trade Commission, Washington, D.C.

Habbershon, T.J. \& Williams, M.L. 1999. A resource-based framework for assessing the strategic advantages of family firms, Family Business Review, 12(1): 1-22.

Heugens, P.P.M.A.R., van Essen, M., \& van Oosterhout, J.H. 2009. Meta analyzing ownership concentration and firm performance in Asia: Towards a more fine grained understanding. Asia Pacific Journal of Management, advance online publication September 25, doi: 10.1007/s10490008-9109-0.

Hill, C.W., \& Snell, S.A. 1988. External control, corporate strategy, and firm performance in research-intensive industries. Strategic Management Journal, 9(6): 577-590.

Johanson, J., \& Vahlne, J.E. 1977. The internationalization process of the firm: A model of knowledge development and increasing market commitments. Journal of International Business Studies, 8: 23-32.

Khanna, T., \& Palepu, K. 1997. Why focussed strategies might be wrong for emerging markets Harvard Business Review, 74: 41-50.

KPMG (2006) The Indian Pharmaceutical Industry: Collaboration for Growth, KPMG London.

Lippman, S. A. and Rumelt, R. P. (1982), Uncertain Imitability: An Analysis of Interfirm Differences in Efficiency Under Competition, Bell Journal of Economics, 13 (2): 418.

Lien, Y.-C., Piesse, J., Strange, R., \& Filatotchev, I. 2005. The role of corporate governance in FDI decisions: Evidence from Taiwan. International Business Review, 14: 739-763.

Mathews, J.A. 2006. Dragon multinationals: New players in $21^{\text {st }}$ century globalisation. Asia Pacific Journal of Management, 23(1): 5-27.

Meyer, K.M., Estrin, S., Bhaumik, S.K., \& Peng, M. 2009. Institutions, resources, and entry strategies in emerging economies. Strategic Management Journal, 30(1): 61-80.

Myers, S.C. (1984) ‘Capital Structure Puzzles’, Journal of Finance, 39 (3): 575-92.

Nayyar, D. 2008. The internationalization of firms from India: Investment, mergers and Acquisitions. Oxford Development Studies, 36(1): 111-131. 
North, D.C. 2005. Understanding the process of economic change. Princeton, NJ: Princeton University Press.

Peng, M.W., Wang, D.Y.L., \& Jiang, Y. 2008. An institution-based view of international business strategy. Journal of International Business Studies, 39: 920-936.

Poza, E.J., Alfred, T., \& Maheshwari, A. 1997. Stakeholder perceptions of culture and management practices in family and family firms: A preliminary report, Family Business Review, 10(2): 135-155.

Pradhan, J.P.P \& Singh, N. (2008) Outward FDI and knowledge flows: A study of the Indian automotive sector. MPRA paper no. 12325, University of Munich.

Ramamurti, R. 2009. What have we learned about EMNEs, In R. Ramamurti, \& J.V. Singh (Eds) Emerging Multinationals from Emerging Markets, Cambridge, UK: Cambridge University Press, 2008, Chapter 13.

Ramamurti, R. and Singh, J.V. 2009. Indian multinationals: Generic internationalization strategies, In R. Ramamurti \& J.V. Singh (Eds), Emerging Multinationals from Emerging Markets, Cambridge, UK: Cambridge University Press, 2008, Chapter 6.

Ramaswamy, K., Li, M., \& Veliyath, R. 2002. Variations in ownership behaviour and propensity to diversify: A study of the Indian corporate context. Strategic Management Journal, 23: 345358.

Rugman, A.M. 1981. Inside the Multinationals: The Economics of Internal Markets, New York: Columbia University Press.

Sarkar, J., \& Sarkar, S. 2000. Large shareholder activism in corporate governance in developing countries: Evidence from India. International Review of Finance, 1(3): 161-194.

Smith, R.J., \& Blundell, R.W. 1986. An exogeneity test for a simultaneous equation Tobit model with an application to labor supply. Econometrica, 54: 679-685.

Tsang, E.W.K. 2001. Internationalizing the family firm: A case study of a Chinese family business. Journal of Small Business Management, 39: 88-94.

Villalonga, B. \& Amit, R. 2006. How do family ownership, control and management affect firm value? Journal of Financial Economics, 80: 385-417.

Yamakawa, Y., Peng, M.W. \& Deeds, D.L. 2008. What drives new ventures to internationalize from emerging to developed economies? Entrepreneurship Theory and Practice, 32(1): 59-82.

Yang, X., Jiang, Y., Kang, R. \& Ke, Y. 2007. A comparative analysis of the internationalization of Chinese and Japanese firms. Asia Pacific Journal of Management, advance online publication November 10, doi: 10.1007/s10490-007-9065-0.

Yoshikawa, T., \& McGuire, J. 2008. Change and continuity in Japanese corporate governance. Asia Pacific Journal of Management, 25(1): 5-24. 
Young, M.N. Mike W. Peng, M.W., Ahlstrom, D., Bruton, G.D \& Jiang.Y 2008. Corporate governance in emerging economies: A review of the principal-principal perspective. Journal of Management Studies, 45(1): 196-220.

Zahra, S.A. 2003. Entrepreneurial risk taking in family firms. Family Business Review, 18: 23-40.

Zhang, J. \& Ma, H. 2008. Adoption of professional management in Chinese family business: A multilevel analysis of impetuses and impediments. Asia Pacific Journal of Management, advance online publication May 10, doi: 10.1007/s10490-008-9097-0. 
Table 1: Descriptive statistics and correlations

\begin{tabular}{|c|c|c|c|c|c|c|c|c|c|c|c|c|c|c|c|}
\hline & Mean & Std. Dev. & FDIASS & SALES & CASH & AGE & FAM & BGR & $\begin{array}{l}\text { SHARE } \\
\text { CON }\end{array}$ & INDSUB & F25 & F10 & INTAN & TDTA & PROFIT \\
\hline FDIASS & 0.011 & 0.061 & 1.00 & & & & & & & & & & & & \\
\hline SALES & 98504 & 27176 & 0.08 & 1.00 & & & & & & & & & & & \\
\hline $\mathrm{CASH}$ & 12780 & 52792 & 0.01 & 0.22 & 1.00 & & & & & & & & & & \\
\hline AGE & 48.3 & 124.5 & 0.01 & 0.01 & 0.01 & 1.00 & & & & & & & & & \\
\hline FAM & 0.176 & 0.381 & $-0.36^{* *}$ & 0.03 & -0.03 & 0.00 & 1.00 & & & & & & & & \\
\hline$\overline{B G R}$ & 0.088 & 0.011 & $-0.34 * *$ & -0.02 & 0.10 & -0.02 & 0.25 & 1.00 & & & & & & & \\
\hline SHARECON & 0.171 & 1.221 & -0.03 & 0.02 & 0.19 & 0.01 & -0.01 & 0.11 & 1.00 & & & & & & \\
\hline INDSUB & 0.064 & 0.246 & 0.40 & 0.12 & 0.00 & 0.00 & -0.03 & -0.05 & -0.02 & 1.00 & & & & & \\
\hline F25 & 0.095 & 0.294 & 0.10 & 0.02 & 0.15 & 0.00 & 0.01 & 0.03 & 0.23 & -0.01 & 1.00 & & & & \\
\hline F10 & 0.330 & 0.419 & 0.05 & -0.06 & 0.00 & 0.00 & 0.00 & 0.08 & 0.08 & 0.00 & -0.03 & 1.00 & & & \\
\hline INTAN & 1.535 & 7.909 & $0.20^{*}$ & $0.23^{*}$ & 0.03 & 0.02 & 0.04 & 0.06 & 0.15 & 0.11 & 0.06 & 0.09 & 1.00 & & \\
\hline TDTA & 0.120 & 0.488 & -0.01 & -0.02 & 0.05 & 0.02 & -0.02 & 0.04 & 0.00 & -0.01 & 0.01 & 0.00 & -0.03 & 1.00 & \\
\hline PROFIT & 0.181 & 0.397 & -0.01 & 0.00 & $0.73^{* *}$ & 0.00 & -0.02 & 0.11 & 0.18 & -0.01 & 0.10 & 0.02 & 0.05 & 0.05 & 1.00 \\
\hline$\overline{\text { CAR }}$ & 0.032 & 0.177 & 0.05 & -0.04 & 0.00 & 0.01 & -0.01 & 0.05 & -0.08 & -0.03 & 0.04 & -0.08 & -0.01 & -0.03 & -0.03 \\
\hline
\end{tabular}

** correlations significant at $5 \%$ level, * significant at $10 \%$ level. 
Table 2: The baseline model

\begin{tabular}{|c|c|c|c|c|c|c|}
\hline & \multicolumn{2}{|c|}{ Full sample } & \multicolumn{2}{|c|}{ Automotive } & \multicolumn{2}{|c|}{ Pharmaceutical } \\
\hline & Coefficient & t-statistic & Coefficient & t-statstic & Coefficient & t-statistic \\
\hline Constant & -0.78 & $-12.49 * *$ & -1.16 & $-8.11^{* *}$ & -0.66 & $-11.09 * *$ \\
\hline SALES & 0.09 & $2.71 * *$ & 0.06 & $4.34^{* *}$ & 0.05 & $2.32 * *$ \\
\hline CASH & 0.18 & $1.96 * *$ & 0.61 & $2.02 * *$ & 0.02 & $1.88^{*}$ \\
\hline AGE & 0.09 & 1.16 & -0.04 & -1.58 & 0.11 & $2.02 * *$ \\
\hline INDSUB & 0.01 & $6.57 * *$ & 0.45 & $9.19 * *$ & 0.01 & $7.79 * *$ \\
\hline INTAN & 0.47 & $7.42 * *$ & 0.10 & $2.68 * *$ & 0.32 & $6.69 * *$ \\
\hline TDTA & -0.04 & $-3.67 * *$ & -0.02 & - 1.89* & -0.02 & $-2.87 * *$ \\
\hline PROFIT & 0.05 & $2.71^{* *}$ & 0.02 & 2.87 & 0.00 & $2.28 * *$ \\
\hline CAR & 0.10 & $2.30 * *$ & & & & \\
\hline Regions & \multicolumn{2}{|c|}{ Yes } & \multicolumn{2}{|c|}{ Yes } & \multicolumn{2}{|c|}{ Yes } \\
\hline$\sigma$ & 0.29 & 13.54 & 0.41 & 12.69 & 0.26 & 10.58 \\
\hline $\log L$ & \multicolumn{2}{|c|}{-501.28} & \multicolumn{2}{|c|}{-383.47} & \multicolumn{2}{|c|}{-288.24} \\
\hline (Pseudo) $\mathrm{R}^{2}$ & \multicolumn{2}{|c|}{0.327} & \multicolumn{2}{|c|}{0.387} & \multicolumn{2}{|c|}{0.377} \\
\hline $\operatorname{corr}(Y, \hat{Y})$ & \multicolumn{2}{|c|}{0.651} & \multicolumn{2}{|c|}{0.657} & \multicolumn{2}{|c|}{0.701} \\
\hline Observations & \multicolumn{2}{|c|}{5410} & \multicolumn{2}{|c|}{1350} & \multicolumn{2}{|c|}{4060} \\
\hline
\end{tabular}

** significant at $1 \%$ level * significant at $10 \%$ level. 
Table 3: Tobit estimates

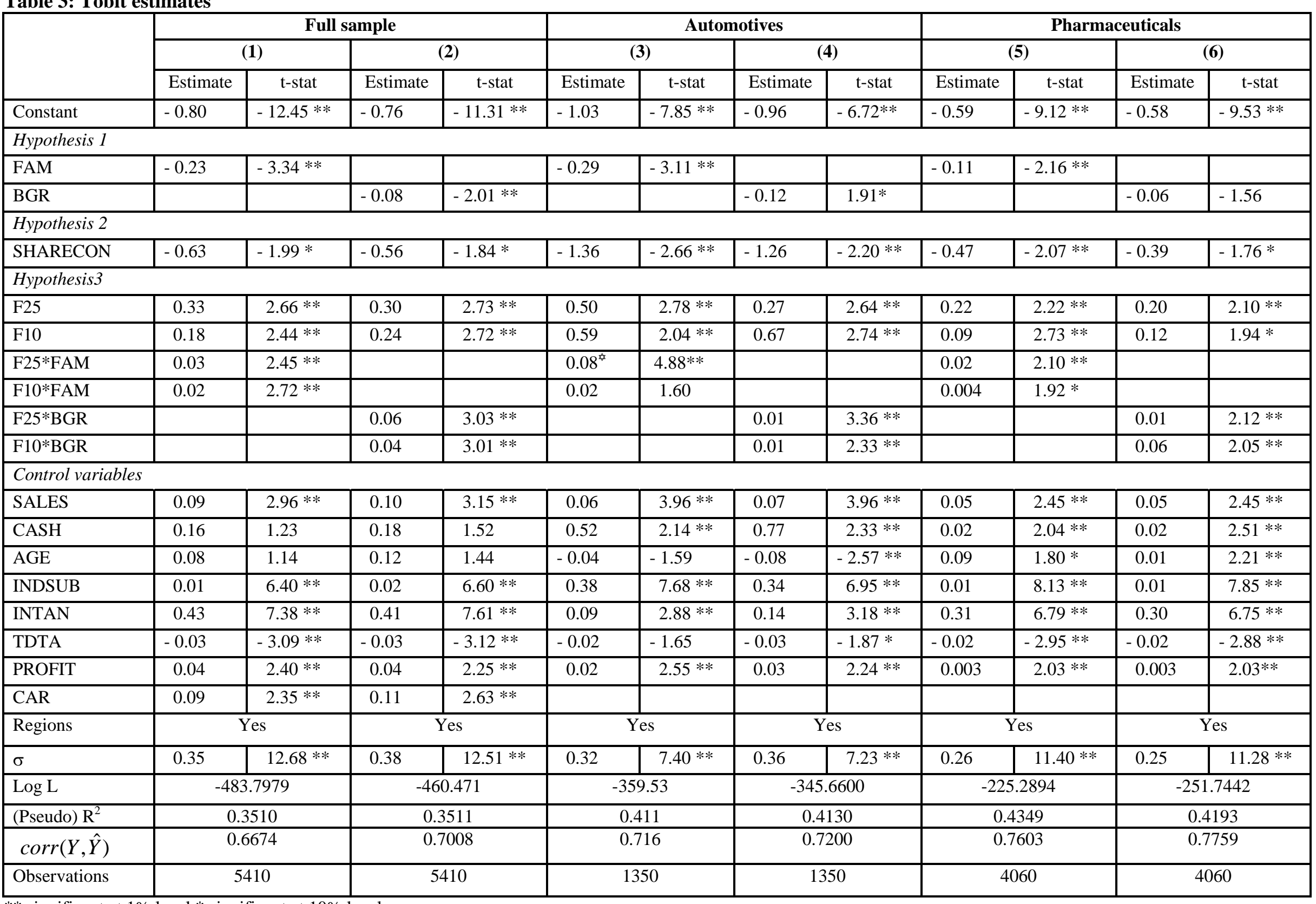

** significant at $1 \%$ level * significant at $10 \%$ level.

* There are only 4 family firms with $25 \%$ foreign ownership in the automotive sector. 
Table 4: Tobit estimates for the model with continuous measures of family ownership

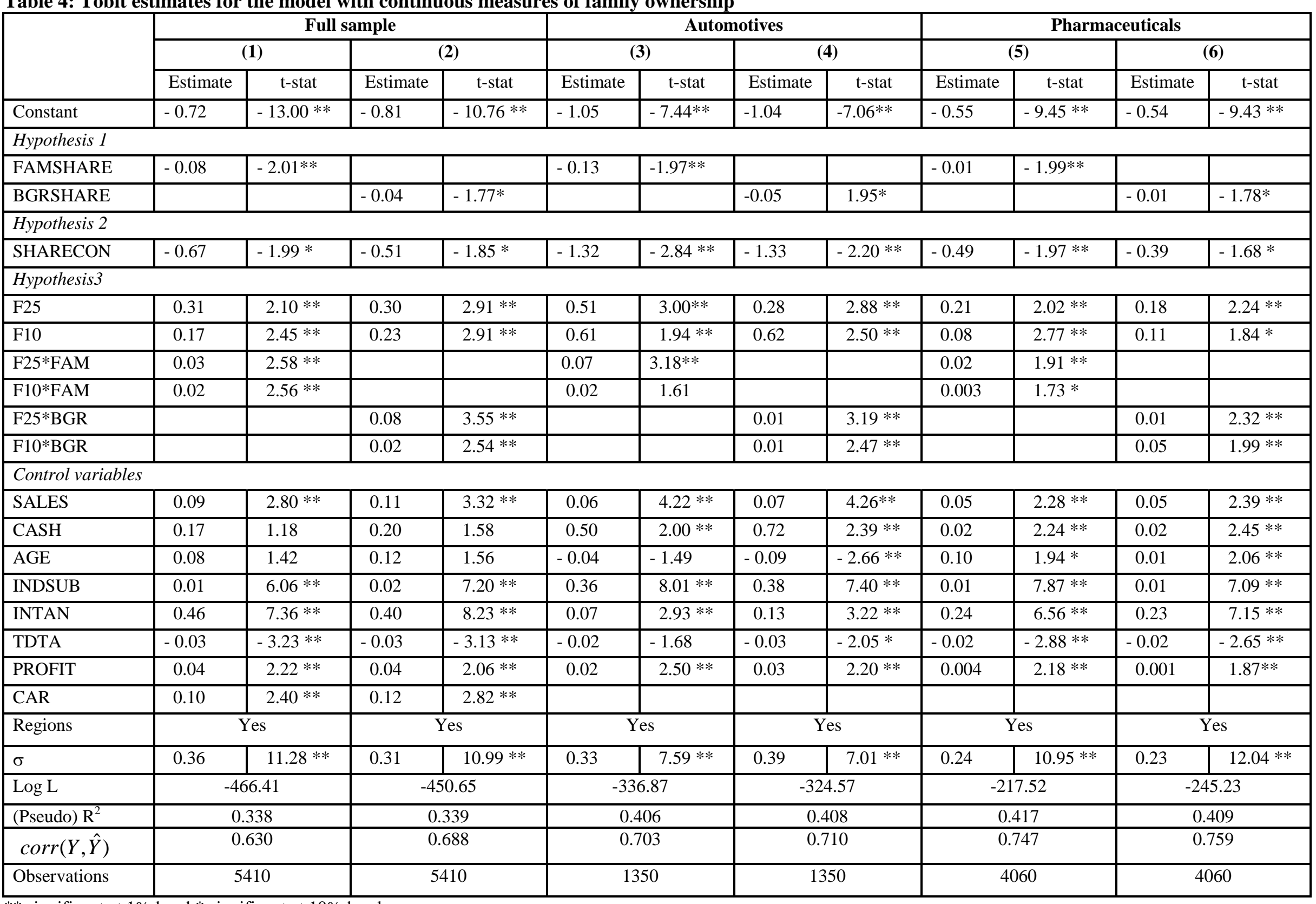

** significant at $1 \%$ level * significant at $10 \%$ level. 